\title{
The Distribution of Zinc Selenite and Expression of Metallothionein- III mRNA in the Spinal Cord and Dorsal Root Ganglia of the Rat Suggest a Role for Zinc in Sensory Transmission
}

\author{
Rubén A. Velázquez, ${ }^{1}$ Yongjiu Cai,,2 Qiuying Shi, ${ }^{2}$ and Alice A. Larson,, 1,2 \\ ${ }^{1}$ Graduate Program in Neuroscience and ${ }^{2}$ Department of Veterinary PathoBiology, University of Minnesota, \\ St. Paul, Minnesota 55108
}

Zinc appears to play a role in synaptic transmission in the hippocampus. We tested the hypothesis that zinc is similarly involved in sensory transmission by determining whether vesicular zinc and metallothionein-III (MT-III), a zinc-binding protein, are localized in rat primary afferent neurons. MT-III mRNA, measured using RT-PCR, and MT-III immunoreactivity, were both present in the spinal cord as well as the thoracic and lumbar dorsal root ganglia (DRG). At a time (24 hr) that allows retrograde transport of zinc selenite to cell bodies, only smalldiameter neurons and neurons scattered throughout lamina $\mathrm{V}$ of the spinal cord were stained by sodium selenite injected intrathecally. This stain disappeared if a ligature was placed on the dorsal root to block axonal transport, demonstrating that these cells are, in fact, zinc-containing primary afferent neurons. When assessed $1 \mathrm{hr}$ after sodium selenite, stain was distributed throughout the neuropil of the spinal cord, especially in lamina
III and the area surrounding the central canal. Even in rhizotomized animals, large- and small-diameter DRG neuronal cell bodies were also stained with either selenite (1 hr) or 6-methoxy 8-para-toluene sulfonamide quinoline (TSQ). Paradoxically, this unique pool of zinc was eliminated in large-diameter DRG neurons after neonatal capsaicin treatment, which had no effect on selenite stain or MT-III mRNA content in small-diameter DRG neurons. In summary, we demonstrate that there is a population of capsaicin-insensitive small-diameter primary afferent neurons that are zinc-containing. In addition, there is a unique pool of capsaicin-sensitive zinc that is associated with largediameter cell bodies.

Key words: zinc; sensory systems; dorsal horn; spinal cord; dorsal root ganglia; sodium selenite; RT-PCR; immunofluorescence
Zinc is a trace element essential for the development of the CNS. The largest concentration of zinc in the brain is found in the hippocampus (Donaldson et al., 1973; Christensen et al., 1992) where it has been studied for its possible role in memory (Xie and Smart, 1994) and neurotoxicity (Choi et al., 1988; Lees et al., 1990). Zinc is sequestered and released from hippocampal neurons, suggesting a possible modulatory role (Assaf and Chung, 1984; Howell et al., 1984; Aniksztejn et al., 1987; Frederickson, 1989).

Metallothionein-III (MT-III) may play a role in the availability of zinc because it has been found in areas of the brain capable of concentrating and releasing zinc, and it is expressed most abundantly in large neuronal cell bodies in the brain (Masters et al., 1994). Zinc ions in the extracellular fluid are thought to serve a modulatory function because zinc is released with excitatory amino acids and inhibits responses to NMDA (Peters et al., 1987; Christine and Choi, 1990) and GABA (Westbrook and Mayer, 1987; Celestiano et al., 1991) by a direct interaction with sites on these receptor complexes. In contrast, non-NMDA responses in

Received June 30, 1998; revised Dec. 23, 1998; accepted Jan. 4, 1999.

This research was supported by National Research Service Award NS09882 to R.A.V., United States Public Health Service Grants NIDA07234 to Y.C. and NIDA04090 to A.A.L. We thank Dr. Richard D. Palmiter for the gift of MT-I and -III cDNA, Dr. Paul E. Fraser for the gift of anti-MT-III antibody, Dr. Christopher J. Frederickson for his invaluable advice on the zinc selenite stain, and Dr. Susan L. Giovengo, Mr. Luis E. Vázquez, Ms. Maria Evensjö, and Mrs. Angela Spartz for their technical assistance.

Correspondence should be addressed to Dr. Alice A. Larson, Department of Veterinary PathoBiology, 295 Animal Science/Veterinary Medicine Building, 1988 Fitch Avenue, St. Paul, MN 55108.

Copyright (C) 1999 Society for Neuroscience $0270-6474 / 99 / 192288-13 \$ 05.00 / 0$ the hippocampus are enhanced in the presence of zinc (Koh and Choi, 1988; Shiraishi et al., 1993; Weiss et al., 1993), supporting a possible role for zinc in neurotoxicity.

The distribution of zinc in the CNS can be visualized using either sodium selenite stain or the fluorescent marker 6-methoxy 8-para-toluene sulfonamide quinoline (TSQ) (Dansher 1982, 1984; Frederickson et al., 1987; Howell et al., 1991; Mandava et al., 1993). These techniques allow differentiation between pools of vesicular versus metabolic zinc as they selectively stain zinc that is highly concentrated in nerve terminals (Perez-Clausell and Danscher, 1985) where it appears to be stored for release.

Behavioral studies in our laboratory indicate that release of zinc into the extracellular fluid of the spinal cord may play a modulatory role in nociception (Larson and Kitto, 1997). Intrathecal injection of zinc produces antinociception in the writhing assay, whereas chelation of zinc in the extracellular fluid, by injection of dipicolinic acid, a zinc chelator, produces hyperalgesia in the tail-flick assay. Thus, our working hypothesis was that zinc is involved in sensory processing and is, therefore, packaged and stored in vesicles of primary afferent neurons. To test this, we used RT-PCR to measure MT-III mRNA in the dorsal root ganglia (DRG). Immunofluorescence and confocal microscopy were used to determine the distribution of MT-III immunoreactivity in the spinal cord and DRG. We also used sodium selenite and TSQ to determine the distribution of vesicular zinc in sensory neurons with a special focus on small-diameter primary afferent neurons that are activated by nociceptive stimuli and believed to be involved in pain transmission. We characterized the distribution of zinc and MT-III mRNA in sensory neurons of rats treated 


\begin{tabular}{|c|c|c|c|c|c|}
\hline Primer & $\begin{array}{l}\text { Size of amplified } \\
\text { fragment (bp) }\end{array}$ & Primer sequence $\left(5^{\prime} \rightarrow 3^{\prime}\right)$ & $\begin{array}{l}\text { GenBank } \\
\text { location }\end{array}$ & $\begin{array}{l}\text { Accession } \\
\text { No. }\end{array}$ & $\begin{array}{l}\text { Reference of the } \\
\text { primer design }\end{array}$ \\
\hline \multirow[t]{2}{*}{ GAPDH } & 335 & GTGGACATTGTTGCCATCAACGAC & $147-170$ & X02231 & Fort et al. (1985) \\
\hline & & TTTCTCGTGGTTCACACCCATCAC & $459-482$ & & \\
\hline \multirow[t]{2}{*}{ MT-I } & 180 & ATGGACCCCAACTGCTCCTGCTCCA & $71-95$ & G205533 & Andersen et al. (1986) \\
\hline & & ACAGCACGTGCACTTGTCCGAGGCA & $852-876$ & & \\
\hline \multirow[t]{2}{*}{ MT-III $^{a}$} & 201 & ATGGACCCTGAGACCTGCCCCTGT & $62-85$ & & Kobayashi et al. (1993) \\
\hline & & TCACTGGCAGCAGCTGCATTTCTCG & $437-462$ & & \\
\hline
\end{tabular}

${ }^{a}$ The MT-III primers were used by Amoureux et al. (1995).

neonatally with capsaicin, the pungent compound of red peppers. Among its effects, capsaicin has been found to be neurotoxic to a large population of small-diameter primary afferent neurons when injected neonatally. This allows it to be extensively used to study the role of these neurons in nociceptive transmission.

\section{MATERIALS AND METHODS}

Animals. For measurement of MT-III, six vehicle-injected and seven neonatally capsaicin-treated male Sprague Dawley rats (Harlan Sprague Dawley, Indianapolis, IN) weighing 250-300 gm were used. Rats were allowed ad libitum access to food and water. They were housed in a room where temperature was controlled constantly at $20^{\circ} \mathrm{C}$ with a $12 \mathrm{hr}$ light/dark cycle for $8 \mathrm{~d}$ before tissue collection.

For studies of zinc histochemistry and MT-III immunohistochemistry, a total of 48 rats weighing 350-450 gm were used. Both male and female animals were used. Rats were sex- and size-matched between control and treatment groups (including the neonatally treated vehicle and capsaicin rats). Animals were allowed ad libitum access to food and water, allowed to acclimate for at least $24 \mathrm{hr}$ before use, and always used during the light period of the cycle. Animals were used strictly in accordance with the guidelines of the University of Minnesota Animal Care and Use Committee and those prepared by the Committee on Care and Use of Laboratory Animals of the Institute of Laboratory Animal Resources, National Research Council [DHEW Publication (National Institutes of Health) 78-23, revised 1978].

Neonatal capsaicin treatment. Rats were injected subcutaneously on postnatal day two with $50 \mathrm{mg} / \mathrm{kg}$ capsaicin diluted in $20 \mu \mathrm{l}$ of vehicle (1:1:8; ethanol:Tween 20:saline). Dams were sedated with sodium pentobarbital during the procedure.

The efficacy of the capsaicin treatment was initially confirmed by a diminished response of the rat to the eye wipe assay at 8 weeks of age. A dilute capsaicin solution ( $50 \mu \mathrm{l}$ of $100 \mu \mathrm{g} / \mathrm{ml}$ ) was applied directly to the cornea of the animals, and the number of aversive responses (closing and pawing directed to the eye) were counted during a 1 min interval. Only capsaicin-treated animals that exhibited a decrease in the number of responses, when compared with vehicle, were used in these experiments.

The efficacy of capsaicin pretreatment was further assessed by the intensity of thiamine monophosphatase (TMPase) stain in alternate tissue sections in experiments examining the distribution of zinc selenite precipitate (see below).

Tissue preparation for $m R N A$ studies. On the sampling day, animals were killed by rapid decapitation. Spinal cords were removed by hydraulic pressure using ice-cold saline and a $30 \mathrm{ml}$ syringe connected to a 14 gauge needle. The spinal cord was washed in ice-cold saline, sectioned in cervical, thoracic, lumbar, and sacral regions, and collected in $1.5 \mathrm{ml}$ Eppendorf tubes, then immediately frozen on dry ice. Thoracic (4-12) and lumbar (1-6) DRG were removed under a dissecting microscope and immediately placed on dry ice. Cortical brain and liver samples were routinely collected as positive and negative controls for MT-III immunoreactivity. All samples were stored at $-80^{\circ} \mathrm{C}$ until isolation of RNA.

MT-III mRNA measurements. RNA was isolated with the Total RNA Isolation System (Promega, Madison, WI) following the manufacturer's instructions. In the present study, DRG and $30-40 \mathrm{mg}$ of brain, liver, and spinal cord samples were homogenized in $400 \mu \mathrm{l}$ of the denaturing solution. The final RNA pellet was dissolved in 10-20 $\mu$ l of the nucleasefree water. The resulting RNA concentrations were estimated spectrophotometrically by measuring absorbancy at $260 \mathrm{~nm}$.
The primers we designed were synthesized and purchased from Life Technologies (Grand Island, NY). We also synthesized a pair of glyceraldehyde-3-phosphate dehydrogenase (GAPDH) primers as controls to assess cDNA quality. The nucleic acid compositions for all primers are listed in Table 1.

Approximately $2 \mu \mathrm{g}$ aliquots of total RNA were used in cDNA synthesis for each sample. All reagents were purchased from Perkin-Elmer (Norwalk, CT) except those specified. The cDNA synthesis was performed in a volume of $20 \mu \mathrm{l}$ containing $1 \times$ PCR buffer II, $5 \mathrm{mM} \mathrm{MgCl}_{2}$, $1 \mathrm{~mm}$ each of dNTPs, $20 \mathrm{U}$ of RNase inhibitor, $2.5 \mu \mathrm{M}$ oligo-d ${ }_{16}$ primer, and $3 \mathrm{U}$ of DNase I (Boehringer Mannheim, Indianapolis, IN). DNA contamination was prevented by incubation of the transcripts with DNase I for $30 \mathrm{~min}$ at $37^{\circ} \mathrm{C}$ followed by heat denaturation of the enzyme for 5 min at $75^{\circ} \mathrm{C}$ (Huang et al., 1996). After $50 \mathrm{U}$ of Moloney murine leukemia virus $(\mathrm{MuLV})$ reverse transcriptase were added to each tube, the reaction proceeded at $25^{\circ} \mathrm{C}$ for $10 \mathrm{~min}, 42^{\circ} \mathrm{C}$ for $1 \mathrm{hr}, 95^{\circ} \mathrm{C}$ for $5 \mathrm{~min}$, and stored at $4^{\circ} \mathrm{C}$ until used for PCR. Two negative controls were used in preparation of reverse transcription mixtures to detect any potential contribution of contaminating genomic DNA or pseudogene product to the PCR signal. The first negative control contained an isolated RNA template from the rat brain, but not the MuLV reverse transcriptase. The second negative control contained all reagents except the RNA template, which was replaced by nuclease-free water.

Optimal PCR conditions were experimentally determined with modifications from Amoureux et al. (1995). Briefly, reactions were performed in a final volume of $25 \mu \mathrm{l}$ containing $1 \mu \mathrm{l}$ of synthesized cDNA, $1 \times$ PCR buffer II, $2 \mathrm{~mm} \mathrm{MgCl}_{2}, 0.2 \mathrm{~mm}$ each of dNTPs, $1 \mathrm{U}$ of AmpliTaq DNA polymerase, and $0.5 \mu \mathrm{M}$ each pair of primers: GAPDH plus MT-I or GAPDH plus MT-III primers. Each experiment included two negative controls, as described above. A positive control contained either MT-I or MT-III, generated by PCR from the rat brain and the mouse MT-I cDNA (a gift of Dr. Richard D. Palmiter at the University of Washington, Seattle, WA), then purified by Geneclean kit (BIO 101, La Jolla, CA). The PCR analysis was amplified 25 cycles for MT-I and 20 cycles for MT-III with 1 min denaturation at $94^{\circ} \mathrm{C}, 1$ min annealing at $60^{\circ} \mathrm{C}$, and 1 min extension at $72^{\circ} \mathrm{C}$. After the last cycle, a final extension was performed at $72^{\circ} \mathrm{C}$ for $5 \mathrm{~min}$. The reaction tubes were stored at $4^{\circ} \mathrm{C}$.

The amplified products were separated by electrophoresis in $1 \times$ Tris acetate for electrophoresis (TAE) buffer with a $2 \%$ agarose gel containing $0.1 \mu \mathrm{g} / \mathrm{ml}$ ethidium bromide. A $100 \mathrm{bp} \mathrm{DNA}$ ladder (Promega) was used as a size marker. The DNA bands were visualized using Eagle Eye II video-imaging system (Stratagene, La Jolla, CA) under UV light, then analyzed using the NIH Image 1.6.0 software on an Apple Power Macintosh computer. We used a two-tailed, unpaired Student's $t$ test for evaluation of the molecular data. A cutoff of $p<0.05$ was used as the accepted level of significance.

We first confirmed that MT-III mRNA is present in the brain but absent in liver using our amplification procedure described above. The mouse brain and liver were homogenized separately, then the brain homogenate was diluted $2 \times$ with the liver homogenate, repeating ten times to produce a total of 11 combined samples that contained the brain homogenate decreasing from $100,50,25,12.5,6.25,3.125,1.562,0.781$, $0.391,0.195$, and $0 \%$, respectively. The eleven combined samples were individually processed for RNA isolation. Two micrograms of total RNA were taken from each of the combined homogenates, then synthesized for cDNA. Two microliters of cDNA was used to amplify MT-III for 20 PCR cycles. The density of bands resulting from these eleven samples were quantified as described above and plotted. 


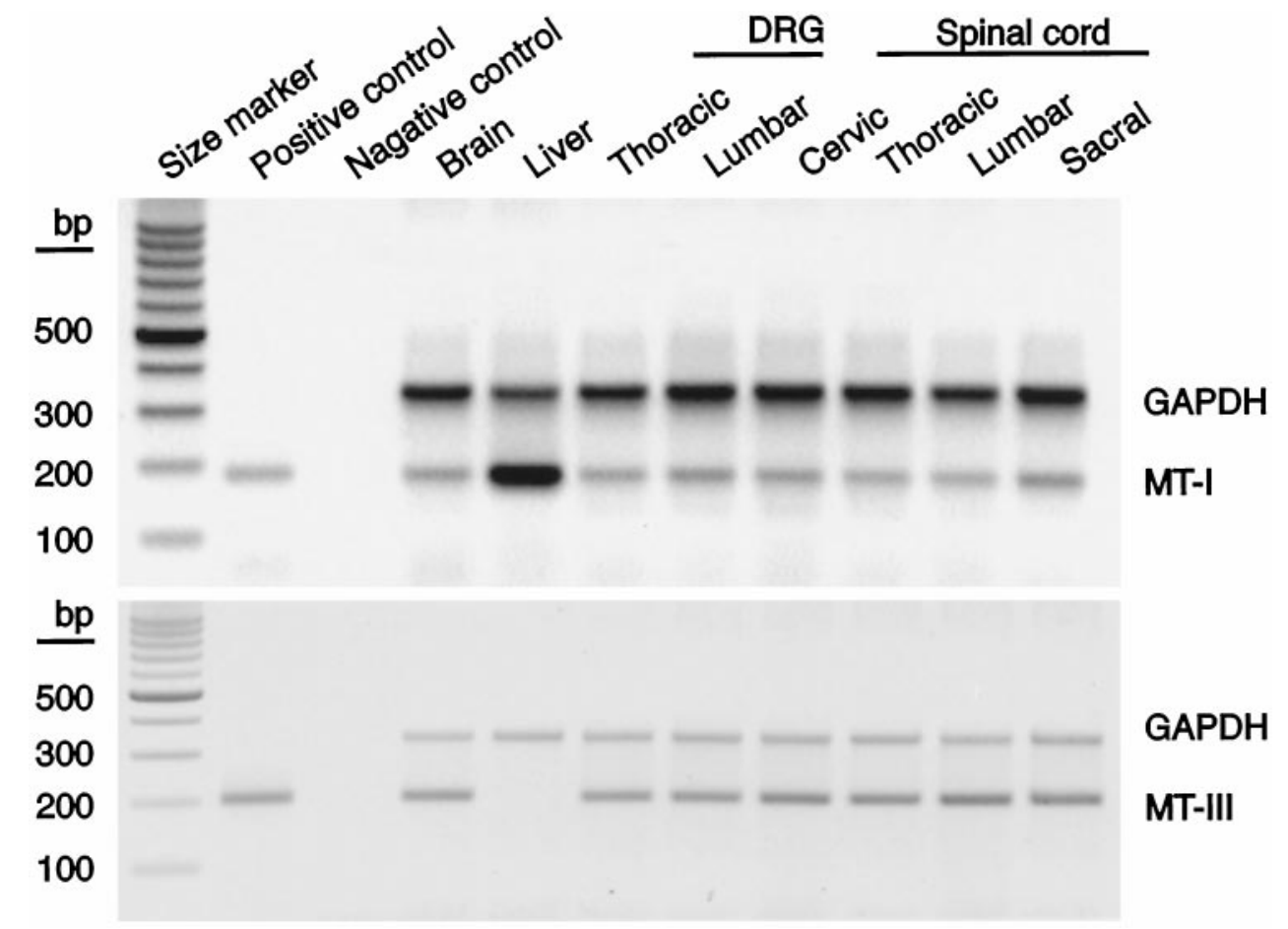

Figure 1. RT-PCR analyses of MT-I and MT-III mRNA expression in the rat brain, liver, thoracic and lumbar dorsal root gan glia $(D R G)$, and all four levels of the spinal cord. The endogenous gene of glyceraldehyde-3-phosphate dehydrogenase (GAPDH) was amplified as an internal control in tissue samples. Negative control contained all reagents except RNA template. MT-I mRNA was found in all tissues tested with the highest level of expression in the liver tissue. MT-III mRNA was found in DRG tissues, the spinal cord, and brain but was missing in the liver.

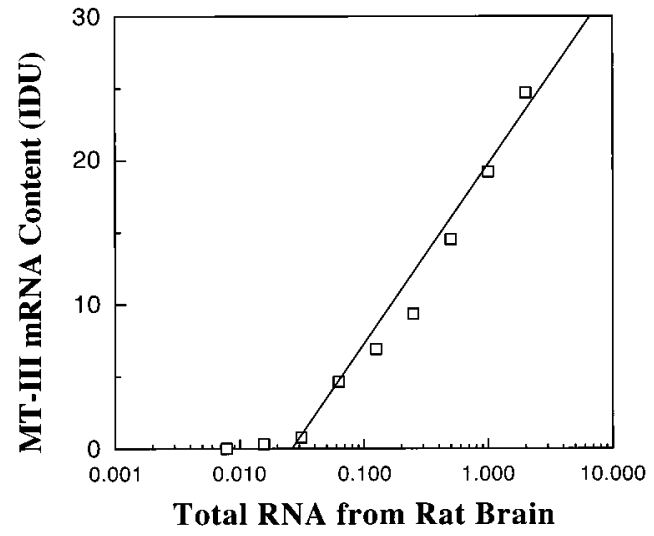

Figure 2. MT-III mRNA expression in brain tissue. Serial dilutions of brain homogenates (where MT-III mRNA is expressed) with liver homogenates (where MT-III mRNA is not found) produce a linear relationship after PCR amplification of MT-III mRNA. This relationship allows for comparisons of MT-III expression in spinal cord and DRG tissues. MT-III mRNA was thereafter quantified and compared over the concentration range that was found to be linear on this standard curve.

Sodium selenite histochemistry. We used several variations of the sodium selenite method to visualize different structures in the CNS. For neuropil staining, animals were injected with $20 \mathrm{mg} / \mathrm{kg}$ sodium selenite intraperitoneally and killed by decapitation $1 \mathrm{hr}$ later. Brain, spinal cord, and lumbar DRG were removed and frozen on dry ice. Also, to identify zinc-containing cell bodies, $9 \mathrm{mg} / \mathrm{kg}$ sodium selenite was injected intraperitoneally, and spinal cord and cortical samples were collected $24 \mathrm{hr}$ after injection. We optimized the sodium selenite methodology to stain cell bodies in the DRG by administering 60 or $150 \mu \mathrm{g}$ of sodium selenite, respectively, diluted in $15 \mu \mathrm{l}$ of saline as an intrathecal bolus. The injection was at approximately the fourth and fifth intervertebral space, using a 1.5-inch-long 25 gauge hypodermic needle and a $50 \mu$ l Hamilton syringe. After $24 \mathrm{hr}$, animals were killed by decapitation, and the spinal cord and DRGs were removed and frozen on dry ice.

All tissues were sectioned at $30 \mu \mathrm{m}$ on a cryostat. Sections from control and treatment groups were thawed onto the same slide to ensure identical processing and air-dried. Three sets of consecutive slides were produced for subsequent silver amplification, cresyl violet, and TMPase stain Sections to be stained by silver amplification were prefixed in $100 \%$ ethanol, rehydrated, coated with $0.5 \%$ gelatin, and air-dried for at least $3 \mathrm{hr}$.

Silver amplification was performed as described by Slomianka et al. (1990). In summary, slides were immersed in a developer solution $[120 \mathrm{ml}$ of $50 \% \mathrm{w} / \mathrm{v}$ gum arabic, $20 \mathrm{ml}$ citrate buffer $\left(25.5 \mathrm{gm}\right.$ citric acid $\cdot \mathrm{H}_{2} \mathrm{O}$, $23.5 \mathrm{gm}$ sodium citrate $\cdot \mathrm{H}_{2} \mathrm{O}$ in $100 \mathrm{ml}$ of nanopure water), $1.7 \mathrm{gm}$ hydroquinone in $30 \mathrm{ml}$ of nanopure water, and $0.22 \mathrm{gm}$ silver lactate in 30 $\mathrm{ml}$ of nanopure water]. Silver lactate was added to the developer in the darkroom immediately before incubation. A $2.5 \mathrm{hr}$ development time was used in all samples.

After development, slides were washed in running water at $40^{\circ} \mathrm{C}$ for 45 min to remove the gelatin coating and washed in nanopure water before the fixation step, consisting of 5\% sodium thiosulfate for $12 \mathrm{~min}$ at room temperature. After fixation, slides were washed in nanopure water for 1 min, post-fixed in $70 \%$ ethanol for $30 \mathrm{~min}$, dehydrated in 95 and $100 \%$ ethanol for $1 \mathrm{~min}$ each, cleared in xylene, and coverslipped with DPX mountant for histology (Fluka, Ronkonkoma, NY).

Consecutive slides were stained in $1 \%$ cresyl violet for histological verification. All compounds were purchased from Sigma (St. Louis, MO) unless otherwise specified.

TMPase stain. We used the methods described by Knyihár-Csillik et al. (1996) without modifications. TMPase is an enzyme found in the subset of nonpeptidergic small-diameter primary afferent neurons (KnyihárCsillik et al., 1986). Because the distribution of TMPase in the spinal cord is limited to small-diameter afferents, TMPase histochemistry serves as a marker for capsaicin-sensitive small-diameter cells in DRG and their projections to lamina II of the dorsal horn of the spinal cord (Mannion et al., 1996). TMPase has been suggested to be the same enzyme as fluoride-resistant acid phosphatase, but TMPase histochemistry produces less nonspecific staining (Knyihár-Csillik et al., 1986). Briefly, slides were rinsed twice for $3 \mathrm{~min}$ in $0.04 \mathrm{M}$ Tris maleate buffer, $\mathrm{pH} 5.0$, then incubated in a fresh solution containing $10 \mathrm{ml}$ of Tris maleate buffer, $\mathrm{pH} 5.0,10 \mathrm{ml}$ of $1.25 \%$ thiamine monophosphate chloride, $20 \mathrm{ml}$ of $0.2 \%$ lead nitrate, and $10 \mathrm{ml}$ of nanopure water at $37^{\circ} \mathrm{C}$. DRG tissue was incubated for $60 \mathrm{~min}$, and spinal cord sections were incubated for $90 \mathrm{~min}$. Slides were rinsed three times for $30 \mathrm{sec}$ in the buffer, developed in $1 \%$ ammonium sulfide (diluted in Tris maleate buffer) for $2 \mathrm{~min}$, and then washed in distilled water for $1 \mathrm{~min}$ followed by a second $3 \mathrm{~min}$ wash in Tris maleate buffer and rinsed 6 times in distilled water for $30 \mathrm{sec}$. Finally, slides were dehydrated in increasing concentrations of ethanol, cleared in xylene, and coverslipped with DPX.

Densitometry. Dorsal horn sections stained for TMPase were digitized using a Scion VG-5 digitizing board connected to a Dage-MIT Nevicon 


\section{A. Dorsal Root Ganglia}

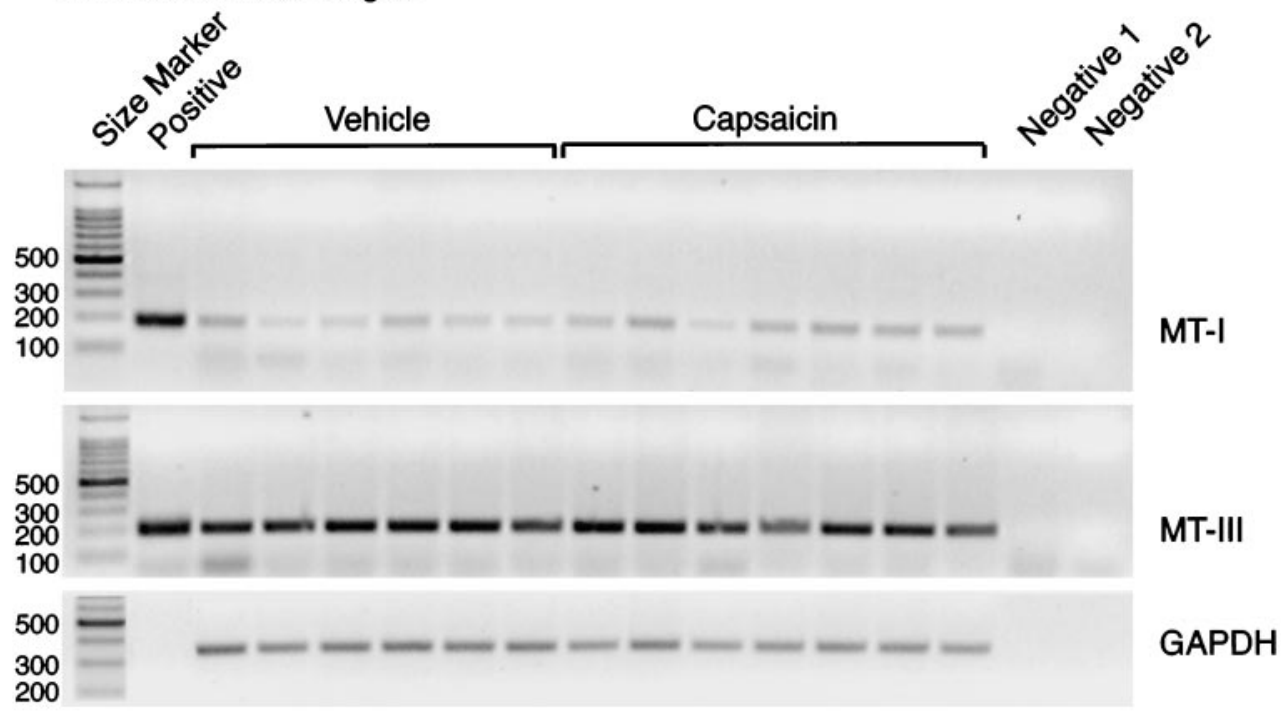

\section{B. Spinal Cord}
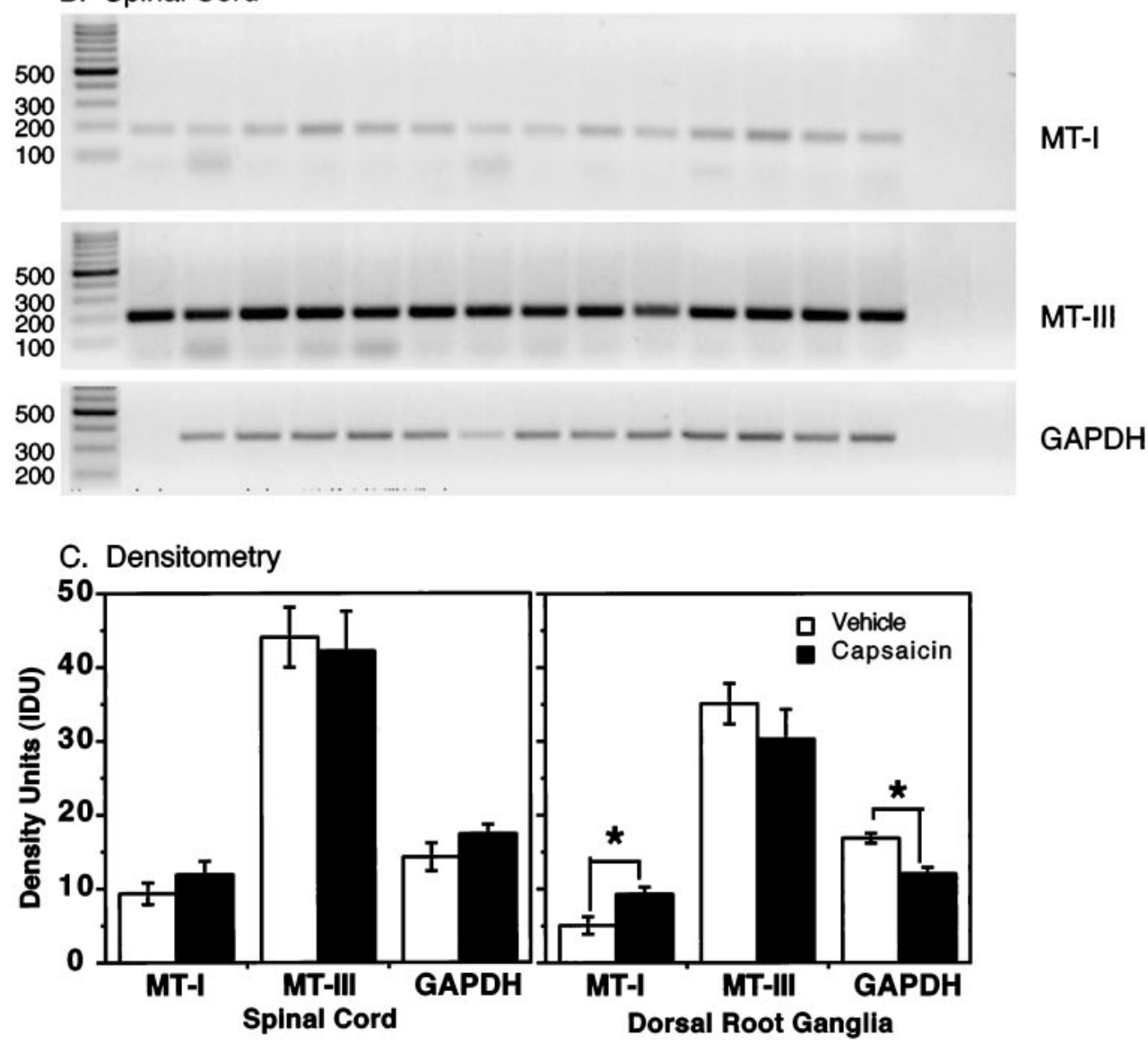

Figure 3. Effect of neonatal capsaicin treatment on MT-I and MT-III mRNA expression in lumbar spinal cord and DRG. Using the NIH Image software densitometric functions, the effect of neonatal capsaicin treatment $(50 \mathrm{mg} / \mathrm{kg}$, s.c. at day 2 postpartum) on MT-I, MTIII, and GAPDH mRNA expression in the lumbar DRG $(A)$ and spinal cord $(B)$ was examined. Densitometric analysis and means ( \pm SEM) are shown in $C$ where the asterisk indicates a significant difference $(p<0.05)$.
CCD camera that is attached to a Nikon Optiphot- 2 microscope. The digital images were analyzed using the densitometric capabilities of the NIH Image 1.60 software installed on a PowerMac 6100/60 equipped with 76 megabytes of random access memory and a 100 megabyte zip drive. When more than one section of the same animal were quantitated, results were averaged before statistical analysis. All images to be compared were digitized the same day using the same acquisition parameters. The measurement area was maintained constant for all groups. Significance was determined using ANOVA and the Fisher's post hoc test. After analysis, images were permanently stored in CD-ROM using a Pinnacle Micro RCD-1000 drive.

$T S Q$ fluorescence. In addition to the selenite method, we used the cell-permeant fluorescent marker TSQ (Molecular Probes, Leiden, The Netherlands) to stain for vesicular zinc, as described by Frederickson et al. (1987). This method has been successfully used to visualize zinc in the hippocampus. Using freshly frozen spinal cords and brains, cryosections at $30 \mu \mathrm{m}$ were collected, mounted onto slides, and air-dried. The sections were then stained for $\sim 90 \mathrm{sec}$ in freshly prepared TSQ and 

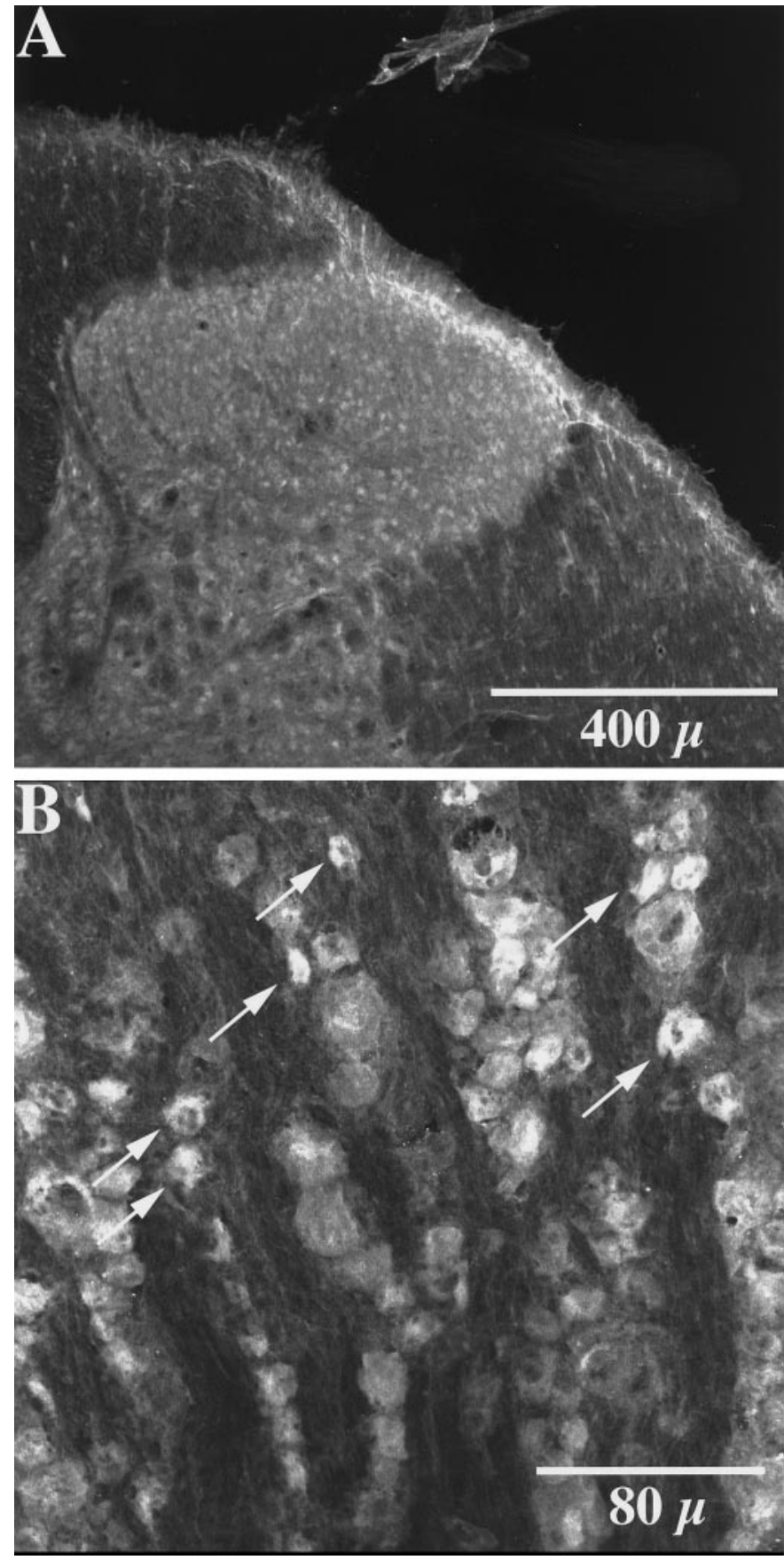

Figure 4. MT-III immunoreactivity is shown in the spinal cord dorsal horn $(A)$ and in both large- and small-diameter neurons in the DRG $(B)$. Arrows indicate small-diameter primary afferent neurons in DRG tissue.

dry-coverslipped. Fresh solutions containing $1.9 \mathrm{gm}$ of sodium acetate, $2.9 \mathrm{gm}$ sodium barbital, and $0.1 \mathrm{ml}$ of $1.5 \%$ TSQ (dissolved in hot ethanol) and adjusted to $\mathrm{pH} 10$ were used in all experiments. Slides were studied under fluorescence using a UV-2A excitation/detection filter for the Nikon Optiphot microscope with epifluorescence attachment.

Immunohistochemistry. Rats were anesthetized with sodium pentobarbital $(60 \mathrm{mg} / \mathrm{kg})$ before transcardial perfusion using $100 \mathrm{ml}$ of ice-cold PBS, pH 7.4, followed by $250 \mathrm{ml}$ of ice-cold PBS containing $4 \%$ formaldehyde and $12.5 \%$ picric acid, $\mathrm{pH}$ 6.9. After perfusion, the spinal cord and DRG were rapidly removed and stored in fixative solution overnight. Then, the tissues were placed in a buffered solution containing 30\% sucrose for $2 \mathrm{~d}$. Using a sliding microtome, spinal cords were sectioned at $40 \mu \mathrm{m}$ and placed on PBS on the day that immunostaining started. DRG were cut in a cryostat at $30 \mu \mathrm{m}$. The tissue slices were placed in a blocker solution for 30 min consisting of $0.1 \%$ saponin and $1 \%$ normal goat serum (Sigma) using PBS as the solvent. Subsequently, the tissues were incubated overnight in the primary antibody containing $1 \%$ normal goat serum, $0.3 \%$ Triton X-100, and rabbit anti-MT-III primary antibody (1:200 dilution, antibody kindly provided by Dr. Paul E. Fraser, University of Toronto, Toronto, Canada). After three 20 min washes with PBS, the tissues were incubated for $3 \mathrm{hr}$ in the secondary antibody solution containing PBS and $1 \%$ normal goat serum, $0.3 \%$ Triton X-100, and donkey anti-rabbit Cy3 secondary antibody (1:600 dilution, Jackson ImmunoResearch Laboratories, West Grove, PA). Finally, the tissues were washed twice for $20 \mathrm{~min}$, soaked overnight with PBS, and coverslipped with DPX solidifying mountant for histology (Fluka). Dorsal horn and DRG sections were digitized using a Bio-Rad (Hercules, CA) 1024 laser confocal microscope at the Imaging Center facilities at the University of Minnesota. Negative controls were performed by using either preimmune rabbit serum (Zymed, San Francisco, CA) or PBS instead of the primary antibody. Liver tissue was also used as negative control for the MT-III antibody because this protein is not expressed in this tissue.

Rhizotomy. To investigate the source of zinc in the DRG, rats were rhizotomized by cutting $(1 \mathrm{hr})$ or tying $(24 \mathrm{hr})$ the dorsal root between the DRG and the spinal cord at the L5-L6 levels. For the $1 \mathrm{hr}$ rhizotomy, rats were anesthetized with an intraperitoneal injection of $0.5 \mathrm{ml}$ of 0.24 $\mathrm{mg} / \mathrm{ml}$ of urethane. More urethane was injected if needed in increments of $0.2 \mathrm{ml}$. A laminectomy was performed removing the vertebrae at levels L4-L6 on both sides of the spinal cord exposing the DRG. Only the DRG of one side were rhizotomized, whereas the contralateral side was used as control. After the rhizotomy, animals were injected with 20 $\mathrm{mg} / \mathrm{kg}$ sodium selenite. One hour later, the DRG were collected and frozen on dry ice. For the $24 \mathrm{hr}$ protocol, rats were anesthetized with 40 $\mathrm{mg} / \mathrm{kg}$ sodium pentobarbital, and then the dorsal root of levels L4 and L5 were tightly tied using surgical silk number 4 , being careful not to damage the dura matter. Then, the animals were injected with $150 \mu \mathrm{g}$ of sodium selenite intrathecally and allowed to recover. Twenty-four hours later, the DRG were collected and frozen in dry ice. Tissue was then processed for the sodium selenite as described above.

\section{RESULTS}

\section{MT-III mRNA expression and MT-III immunohistochemistry}

MT-III mRNA fragments amplified from brain, spinal cord, and DRG matched the target $201 \mathrm{bp}$ band shown in the positive control band for MT-III. Similarly, the amplified MT-I mRNA fragment in tissue was distinct from that of MT-III mRNA and matched the target $180 \mathrm{bp}$ band exhibited by the positive control of MT-I. These results indicate that our PCR primers for MT-III mRNA were selectively amplified and distinct from that of MT-I mRNA. MT-III mRNA was present in the brain and in all levels of the spinal cord, but not expressed in the liver where MT-III has been shown to be absent (Palmiter et al., 1992). In addition, we found that MT-III mRNA was readily expressed in all $(n=6)$ thoracic and lumbar DRG sampled, as shown by the representative gel in Figure 1. This MT-III tissue specificity is consistent with that previously found in rats (Uchida et al., 1991; Palmiter et al., 1992) and mice (Masters et al., 1994).

To validate the RT-PCR method, we measured MT-III mRNA expression in the liver (where no expression was detected) and in the brain (where significant expression was detected) and then diluted the brain total mRNA homogenate consecutively using the liver homogenate and obtained a gradually decreasing density of the MT-III PCR product band (Fig. 2). MT-III mRNA was thereafter quantified and compared over the concentration range that was found to be linear on the standard curve.

The endogenous housekeeping gene GAPDH was amplified in all samples except in the purified positive controls for MT-I and MT-III and in the negative controls where reverse transcriptase or the RNA template were excluded. The expression of GAPDH was used to standardize samples and to ensure a reliable quality of synthesized cDNA. GAPDH is constitutively expressed in 

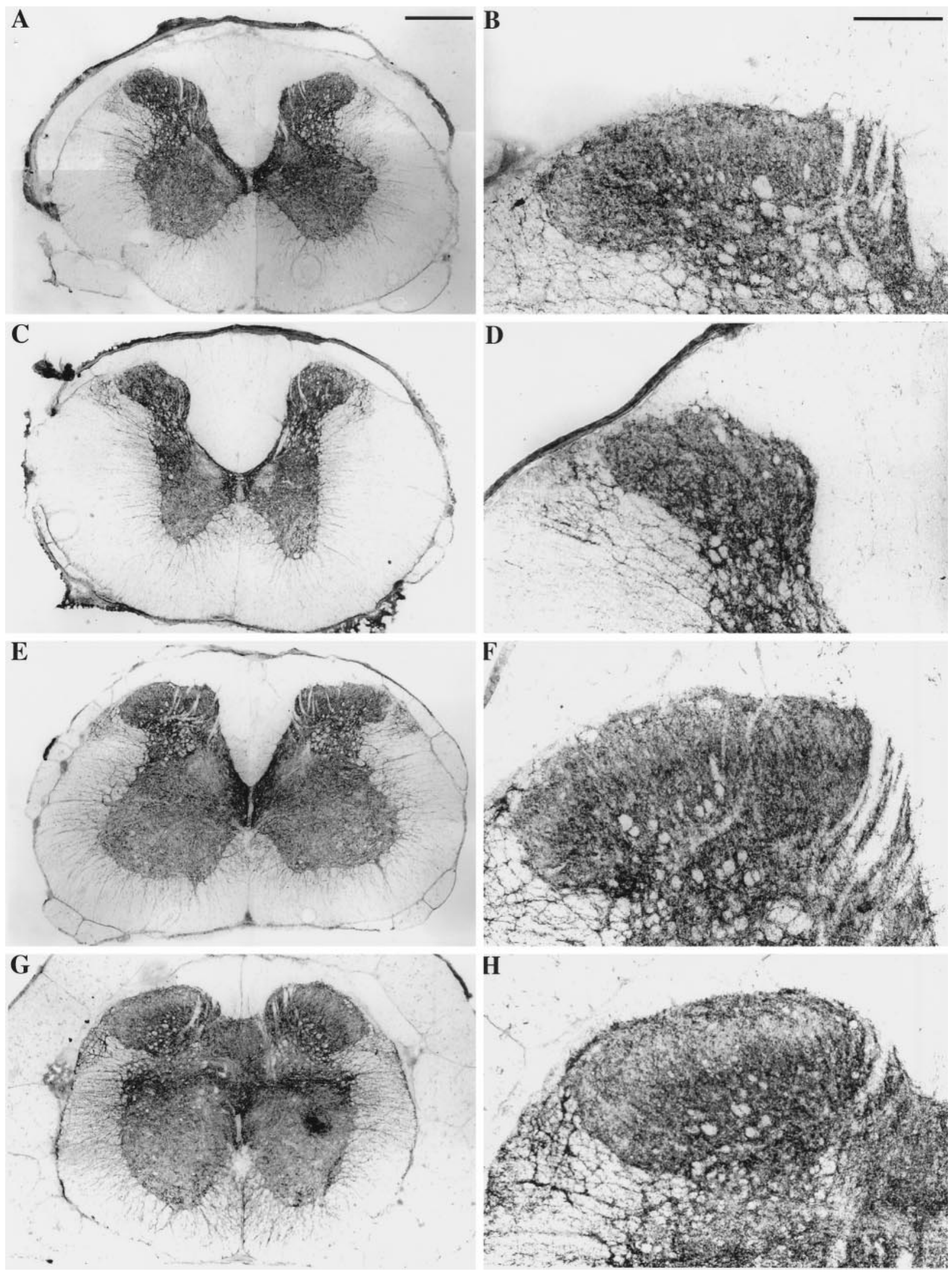

Figure 5. Zinc stain $1 \mathrm{hr}$ after injection of $20 \mathrm{mg} / \mathrm{kg}$ sodium selenite intraperitoneally. Representative microphotographs of cervical $(A, B)$, thoracic $(C, D)$, lumbar $(E, F)$, and sacral $(G, H)$ spinal cord and dorsal horn, respectively. Spinal cord sections (scale bar: $A, C, E, G, 800 \mu \mathrm{m})$ show intense zinc selenite precipitate in the dorsal horn and the area of the central canal. Dorsal horns sections (scale bar: $B, D, F, H, 200 \mu \mathrm{m}$ ) at the right side of the figure show a strong precipitate formation in lamina I and III with an area of lesser stain in lamina II. 

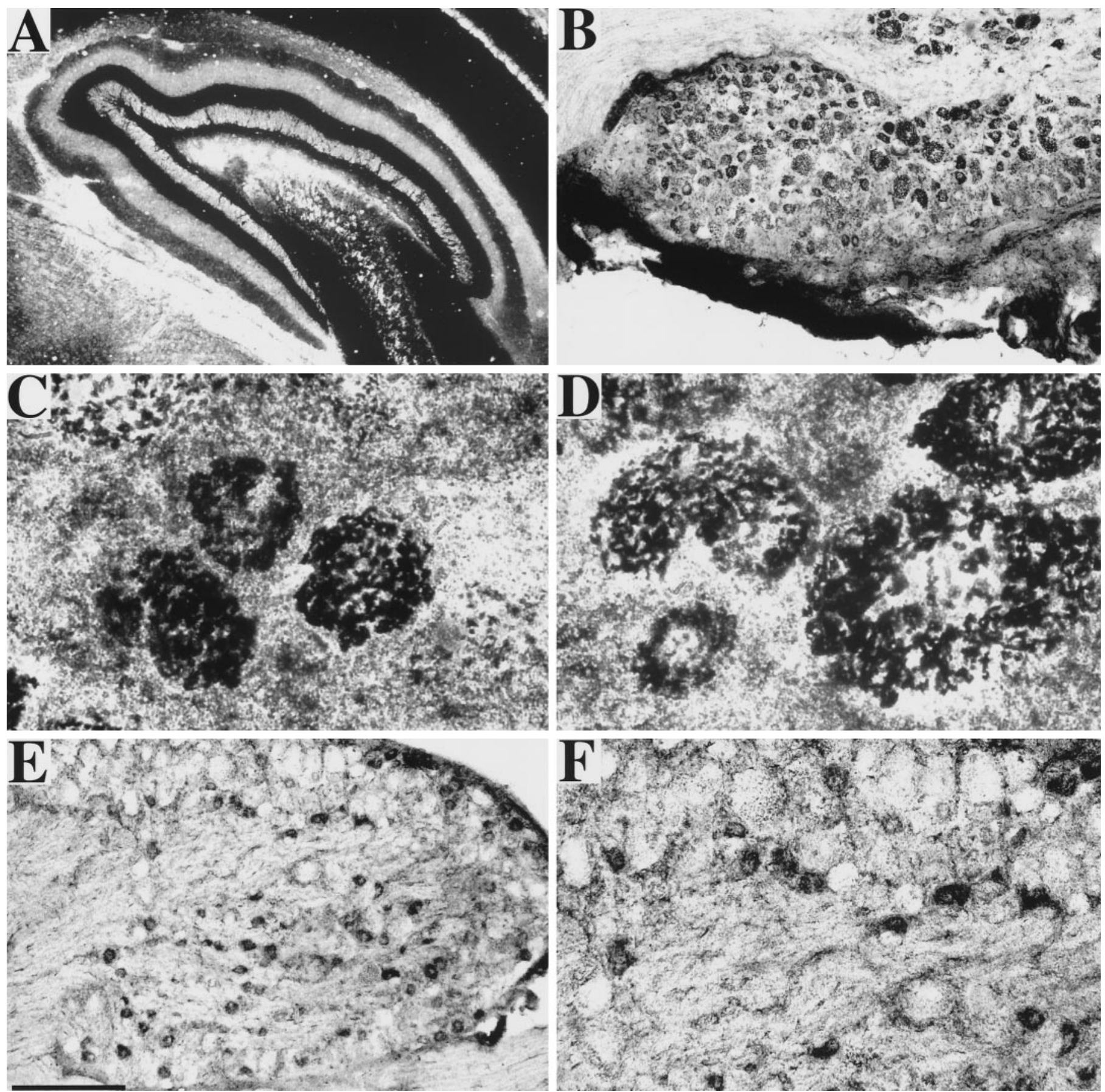

Figure 6. Effect of neonatal capsaicin on stain produced $1 \mathrm{hr}$ after injection of sodium selenite in DRG. A control section of the hippocampus is presented in $A$ for comparison (scale bar, $200 \mu \mathrm{m}$ ). Saline-pretreated $(B-D)$ DRG tissues contained a strong zinc selenite precipitate in small-diameter cells (scale bar: $C, 50 \mu \mathrm{m}$ ) and speckled precipitate in large-diameter cell bodies (scale bar: $D, 50 \mu \mathrm{m}$ ). The precipitate in large-diameter neurons was absent in rats injected neonatally with capsaicin $(E, F)$, but the precipitate in small-diameter cell bodies remained, as in saline-pretreated animals. Scale bar: $E, 200 \mu \mathrm{m} ; F, 100 \mu \mathrm{m}$.

many tissues, allowing it to be used as an internal control for mammalian cells (Dveksler et al., 1992). The absence of a band for the first negative control indicates that there was no cross contamination in the reagents used from cDNA synthesis to PCR processing. The absence of a band for the second negative control is evidence that there was no pseudogene product to the PCR signal. Figure 1 shows only the result of the second negative control.

We measured the content of MT-I and -III mRNA in rats treated neonatally with capsaicin $(n=7)$ and found no difference in the content of MT-III mRNA expressed in control tissue compared with that after treatment with capsaicin with respect to DRG (Fig. 3A,C) and spinal cord tissues (Fig. 3B,C). However, there was a significant increase $(p=0.02)$ in MT-I mRNA in lumbar DRG (Fig. 3C) of rats injected neonatally with capsaicin. No effect of capsaicin was seen on the content of MT-I mRNA in spinal cords of the same animals. A significant decrease $(p=$ $0.001)$ in GAPDH mRNA content was detected in the DRG of 

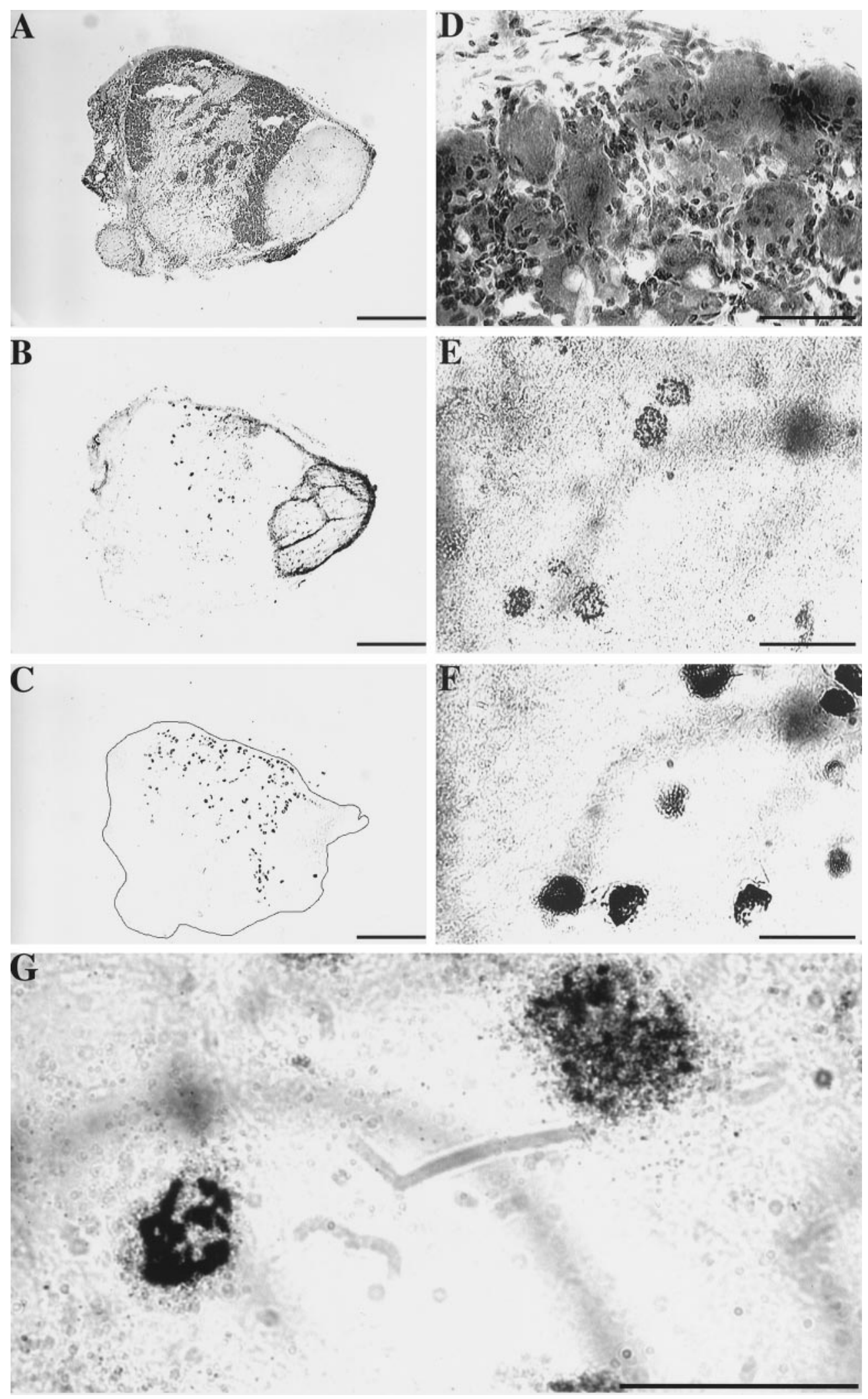

Figure 7. Cells stained at $24 \mathrm{hr}$ after injection of sodium selenite are unique from those that stain for TMPase in the DRG. DRG sections $(30 \mu \mathrm{m})$ stained with cresyl violet $(A, D)$, sodium selenite $(B, E)$, and TMPase $(C, F)$ show that TMPase-positive cells are more widespread in DRG tissue, whereas the selenite-positive cells are present in the central regions of the DRG where TMPase-positive cells are not abundant. High magnification of small-diameter DRG neurons labeled with sodium selenite histochemistry are presented in $G$. Scale bars: $A-C, 600 \mu \mathrm{m} ; D-F$, $50 \mu \mathrm{m}$.

capsaicin-treated animals that was not observed in their spinal cords (Fig. 3C). In view of the toxic effect of capsaicin, the decrease in GAPDH mRNA suggests a decrease in tissue content. Thus, the increase in MT-I mRNA with respect to GAPDH mRNA is even greater after capsaicin pretreatment, suggesting an enrichment of cells synthesizing MT-I.
By using immunohistochemistry and confocal microscopy, MTIII immunoreactivity was found to be expressed in neurons present in almost all laminae of the spinal cord, including the superficial layers of the dorsal horn (Fig. 4A). MT-III immunoreactivity was also found to be expressed in both large and small neurons in the DRG (Fig. 4B). Importantly, MT-III immunore- 

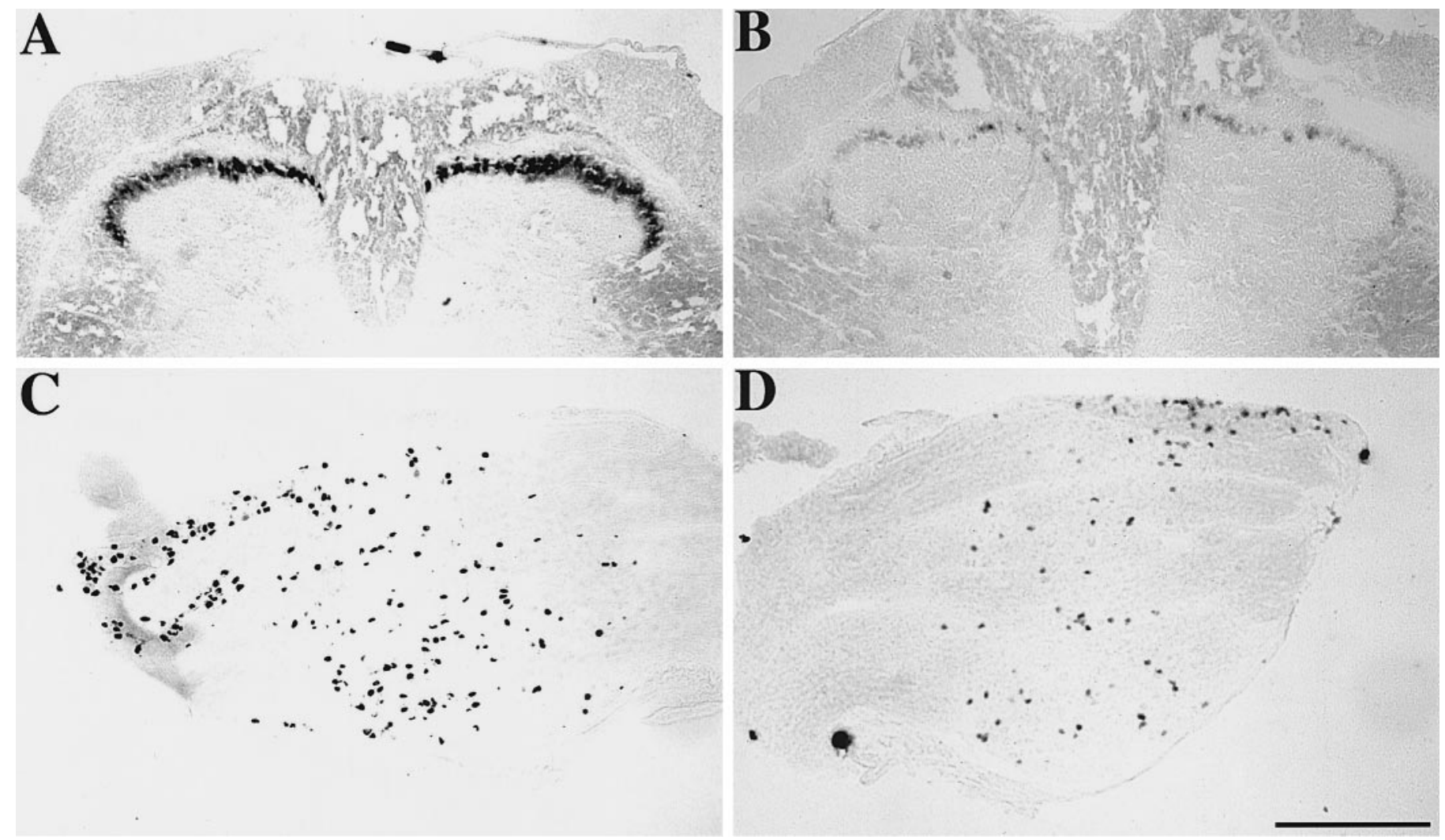

Figure 8. Effect of neonatal capsaicin treatment on TMPase stain. We used TMPase stain to monitor the toxicity of neonatal capsaicin treatment on small-diameter neurons. Saline-pretreated animals have spinal cords with intense TMPase stain in lamina II of the dorsal horn $(A)$ and in most of the small-diameter cells in the DRG $(C)$. Neonatal capsaicin treatment decreased the stain in lamina II of the spinal cord $(B)$ by an average of $56 \%$ and also greatly decreased the number of TMPase-positive cells in the DRG $(D)$. Scale bar: $A-D, 600 \mu \mathrm{m}$.

activity was absent in the liver and in the negative controls as expected.

\section{One hour sodium selenite treatment}

One hour after an intraperitoneal injection of $20 \mathrm{mg} / \mathrm{kg}$ sodium selenite, rats were weak and had profound diarrhea similar to that previously described by Slomianka et al. (1990). The distribution of stain in the brain was highest in the neuropil of the hippocampus, consistent with that previously described in detail (Dansher 1982, 1984; Frederickson et al., 1987, 1988; Slomianka et al., 1990). Tissue from these animals $(n=6)$ also contained a strong zinc selenite precipitate in the area of the central canal and in areas I and III of the dorsal horn of the spinal cord (Fig. 5). This characteristic neuropil stain was present at all levels of the spinal cord. In the same animals, cellular stain was observed associated with neuronal cell bodies of the DRG, a subcellular distribution that is not typical in the brain at $1 \mathrm{hr}$ after administration of selenite. Both large- and small-diameter cells stained in DRG tissue, however, the cellular stain observed in large-diameter neurons consisted of speckles of precipitate, often with a clear center. A concentrated and uniform precipitate was more characteristic in small-diameter cells than those with larger diameters (Fig. 6).

Neonatal capsaicin treatment did not affect the distribution or intensity of selenite stain $(1 \mathrm{hr})$ in the neuropil of the spinal cord $(n=6)$. In the DRG of capsaicin-pretreated rats, however, the speckles of selenite stain in large-diameter cell bodies was conspicuously absent, whereas there was no effect of capsaicin on the more concentrated precipitate in small-diameter DRG neurons $(n=6$; Fig. 6).

\section{Twenty-four hour sodium selenite treatment}

When sodium selenite was administered intraperitoneally at a dose of $9 \mathrm{mg} / \mathrm{kg}, 24 \mathrm{hr}$ before killing, neuronal cell bodies in cortical tissue stained as previously described (Frederickson et al., 1987, 1988; Slomianka et al., 1990). However, no stain was found in either the spinal cord or DRG tissue removed at this time (zero of six animals stained), even when the animals exhibited the characteristic behavior associated with this injection of selenite.

When we administered sodium selenite locally by a spinal injection at a dose of $60 \mu \mathrm{g}$, rats were paralyzed in the lower extremities for $\sim 1 \mathrm{hr}$ after injection. When killed at this time, there was no indication of zinc selenite precipitate in DRG tissue $(n=3)$. After this interval, animals behaved normally. Twentyfour hours after this intrathecal injection of selenite, precipitate was found to be concentrated in DRG cell bodies, consistent with a time interval and distribution that reflects an accumulation after transport of zinc selenite to cell bodies. Neonatal capsaicin treatment had no effect on this distribution of zinc selenite precipitate in DRG cells (Fig. 7B). DRG cells were also stained $24 \mathrm{hr}$ after injection of $150 \mu \mathrm{g}$ of sodium selenite $(22.9 \%$ of the total of small-diameter DRG neurons). These animals were profoundly paralyzed in the lower extremities, an effect that did not dissipate over the next $24 \mathrm{hr}$. After this treatment, spinal cord tissue was extremely swollen. Yet selenite stain was dense in the 

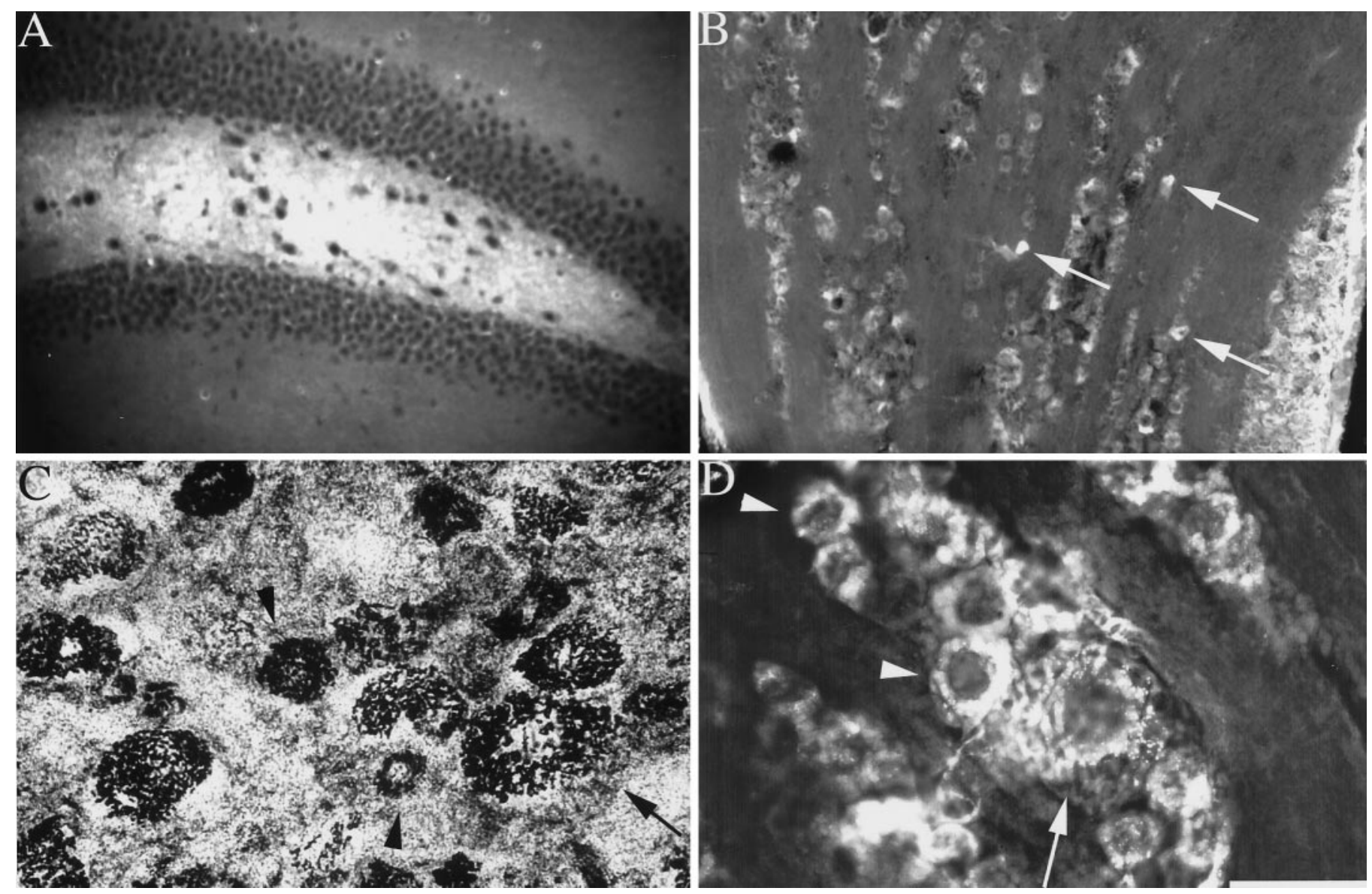

Figure 9. TSQ stain of DRG tissues. Zinc fluorescence in fresh-frozen hippocampus is presented in $A$ for comparison of the stain intensity (scale bar, $400 \mu \mathrm{m}$ ). TSQ fluorescence in the DRG was observed in both large- and small-diameter cell bodies (scale bar: $B, 400 \mu \mathrm{m}$, see arrows) in fresh-frozen DRG. One hour sodium selenite-treated DRG $(C)$ is presented for comparison to TSQ-labeled tissue $(D)$. Arrowheads indicate small-diameter DRG neurons, whereas whole arrows indicate large-diameter DRG neurons. Scale bar: $C, D, 150 \mu \mathrm{m}$.

gray matter, suggesting that it distributed to all areas of the cord. However, in the DRG, only small-diameter cell bodies stained (five of six animals), randomly scattered throughout the DRG (Fig. $7 B, E, G)$. The intensity of stain and number of cells stained were not different in rats treated neonatally with capsaicin than in vehicle-injected controls.

\section{TMPase staining}

The characteristic distribution of TMPase was measured to ensure that neonatal treatment with capsaicin produced histologically measurable effects in the neuropil of lamina II of the spinal cord dorsal horn. TMPase stain in lamina II of the dorsal horn was reduced by $56 \%$ by neonatal treatment with capsaicin compared with that in vehicle-treated animals (Fig. 8A,B). The number of TMPase-positive DRG cell bodies was reduced by $72 \%$ in animals injected neonatally with capsaicin when compared with those treated with vehicle (Fig. $8 C, D$ ). Consecutive slides stained for sodium selenite demonstrated that small DRG cells that stain with TMPase for the most part did not coincide with small DRG cells that stain with zinc selenite precipitate (Fig. $7 B, C$ ). There was an average of only $7.1 \%$ of selenite-positive cells that also stain for TMPase in six rats studied. TMPase histochemistry labeled $56.7 \%$ of the total number of small-diameter DRG neurons.

\section{TSQ fluorescence}

The fluorescent marker TSQ was used to confirm the unique distribution of zinc in DRG. We found that a $90 \mathrm{sec}$ exposure to TSQ that labeled hippocampal tissue used as positive control also labeled both large- and small-diameter cell bodies in DRG tissue (Fig. 9). When tissue pretreated with sodium selenite was stained with TSQ, no fluorescence was detected in DRG tissue, suggesting that both methods compete for the same pool of zinc, further validating the specificity of the techniques.

\section{Rhizotomy}

To determine whether zinc-positive cell bodies in the DRG were stained by fast retrograde transport of zinc selenite precipitate from the spinal cord terminals, we stained zinc using selenite (1 hr) administered intraperitoneally to anesthetized rats after a dorsal rhizotomy. There was no difference in the intensity of stain or number of cell bodies stained in the DRG on the rhizotomized side compared with that on the control side (data not shown) at this time interval. When the dorsal roots were tied using a silk ligature, and the animals were injected with $150 \mu \mathrm{g}$ of sodium selenite intrathecally and allowed to recover for $24 \mathrm{hr}$, there was no detectable zinc selenite precipitate present in the ligated DRG (Fig. $10 B$ ), but staining was present in small-diameter neurons in the contralateral control side (Fig. 10A). 


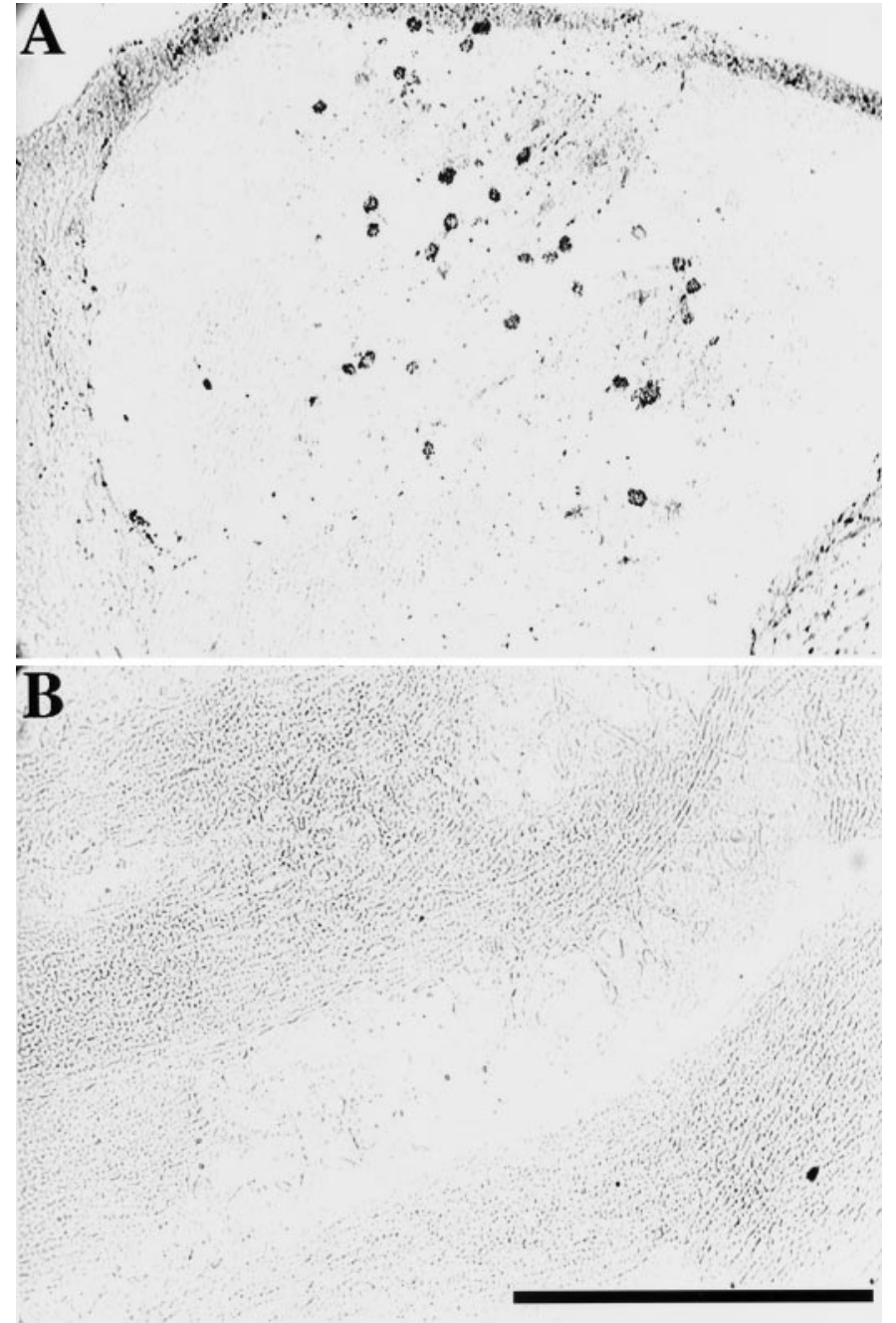

Figure 10. Effect of dorsal root ligature on the $24 \mathrm{hr}$ sodium selenite stain. Twenty-four hours after intrathecal injection of $150 \mu \mathrm{g}$ of sodium selenite, only small-diameter neurons were stained $(A)$. This time interval is sufficient to allow axonal transport of zinc selenite precipitate from the terminal arborizations in the spinal cord. No detectable zinc selenite precipitate was present in DRG in which the dorsal root was ligated with surgical silk before injection of sodium selenite $(B)$. Scale bar: $A, B$, $600 \mu \mathrm{m}$.

\section{DISCUSSION}

Zinc appears to play a role in sensory transmission because there is a population of primary afferent neurons that appears to be zinc-containing. In support of this is the expression of MT-III in DRG and the distribution of selenite stain in small-diameter DRG neurons $24 \mathrm{hr}$ after an intrathecal injection of sodium selenite, a stain that can be abolished by blocking axonal transport. Localization of selenite precipitate in neuronal cell bodies is characteristic of retrogradely transported vesicular zinc, a pattern that has been used to identify zinc-containing cell bodies (Slomianka et al., 1990; Christensen et al., 1992). Consistent with the localization of selenite precipitate, we found MT-III mRNA and MT-III immunoreactivity, reflecting its protein product in both spinal cord and DRG tissue. Metallothionein-III has been found to be synthesized in areas containing neurons capable of concentrating and releasing zinc after electrical stimulation or after the addition of potassium (Masters et al., 1994). Thus, localization of MT-III in DRG suggests a possible role for this metalloenzyme along sensory pathways. Together these data indicate that zinc can be concentrated in and released from a population of zinccontaining primary afferent sensory neurons.

MT-III mRNA expression in the spinal cord and DRG was not affected by neonatal treatment with capsaicin. This insensitivity would argue that zinc-containing afferents do not belong to the class of capsaicin-sensitive neurons expressing the vanilloid receptor-1 (Caterina et al., 1997) commonly associated with nociceptive transmission. The distinct distribution of small DRG cells that stain $24 \mathrm{hr}$ after injection of sodium selenite compared with those that stain with TMPase, which are capsaicin-sensitive, is consistent with the existence of two populations of smalldiameter neurons, i.e., those sensitive to capsaicin that are not zinc-containing and those that are zinc-containing and insensitive to capsaicin. In contrast to MT-III, MT-I mRNA expression was increased in lumbar DRG of rats treated neonatally with capsaicin, despite a small, but significant decrease in the content of GAPDH mRNA in these same tissues. MT-I and MT-II, which are distributed throughout the body, are coordinately upregulated by zinc (Yagle and Palmiter, 1985; Palmiter, 1987) and have been proposed to play a role in divalent cation toxicity (Westbrook and Mayer, 1987; Koh and Choi, 1988; Christine and Choi, 1990; Shiraishi et al., 1993; Weiss et al., 1993). MT-I mRNA is, therefore, likely localized in larger-diameter neurons and/or capsaicininsensitive tissue. There it is either concentrated by the elimination of capsaicin-sensitive neurons that synthesize little or no MT-I or permanently upregulated by the toxic effect of neonatal capsaicin.

It was largely based on the localization of MT-III mRNA and MT-III immunoreactivity in the DRG, that we used selenite stain to identify sensory neurons that are zinc-containing. This protocol has been previously developed to identify zinc-positive neuropil (1 hr after $20 \mathrm{mg} / \mathrm{kg}$ sodium selenite) and neuronal cell bodies ( $24 \mathrm{hr}$ after injection of $9 \mathrm{mg} / \mathrm{kg}$ sodium selenite) in other brain regions (Slomianka et al., 1990). The dense precipitate found $1 \mathrm{hr}$ after selenite in laminae I and III and in the region of the central canal of the spinal cord is consistent with areas involved in sensory processing. However, the injection of $9 \mathrm{mg} / \mathrm{kg}$ selenite intraperitoneally failed to label spinal or DRG cells at 24 $\mathrm{hr}$, suggesting that the concentrations of zinc in these areas are less than in the brain, which contains neurons that are successfully stained using this dose and route of administration. However, it should be remembered that the intensity of stain by this technique depends on the terminal arborization of zinccontaining neurons, which may be less in the DRG neurons. Injection of selenite by an intrathecal route allowed us to increase the availability of selenite in a restricted area, similar to the microinjection of selenite previously used to stain rat cortical neurons (Christensen et al., 1992). Twenty-four hours after an intrathecal injection of selenite, small-diameter DRG cells were selectively stained. Significantly, the staining present in smalldiameter neurons at $24 \mathrm{hr}$ can be blocked by placing a ligature in the spinal root leading to the DRG, effectively blocking axonal transport of the zinc selenite precipitate. Approximately $25 \%$ of the small-diameter DRG neurons are zinc-containing. Neonatal capsaicin treatment did not affect the number nor the intensity of small-diameter cells stained in the DRG. These data, consistent with the results describing MT-III synthesis, indicate that zincpositive cells appear to be small, yet capsaicin-insensitive. These data are also consistent with distinct distributions of selenite and TMPase in cells of both the DRG and laminae of the spinal cord.

Although cell bodies do not usually contain sufficient zinc to 
stain just $1 \mathrm{hr}$ after injection of sodium selenite, both large- and small-diameter neurons in the DRG stained under these conditions. The $1 \mathrm{hr}$ protocol is typically used to identify only neuropil. Because neuronal stain at this time is unprecedented, it is unclear what pool of zinc is reflected in DRG because there are no traditional synapses reported in this tissue. Because of a less restrictive blood-brain barrier, the DRG appears to be more accessible to a variety of compounds (Arvidson and Tjälve, 1986; Gregg et al., 1992). Based on this characteristic, sodium selenite may have merely achieved a higher concentration in this area and, thus, a more prominent stain. However, the fluorescent zinc marker TSQ, whose distribution does not vary with the integrity of the blood-brain barrier as it is applied to tissue slices, also stained both large- and small-diameter DRG cells. TSQ stain further demonstrates the presence of high concentrations of zinc in these neurons.

The cellular stain in large-diameter neurons observed at $1 \mathrm{hr}$ after selenite administered intraperitoneally was absent $24 \mathrm{hr}$ after the intrathecal injection of selenite. This suggests that only the remaining small-diameter neurons that are labeled by retrogradely transported zinc selenite vesicles are, in fact, zinccontaining. The stain observed in large-diameter cell bodies is also absent $1 \mathrm{hr}$ after intraperitoneal injection of selenite in capsaicin-treated animals, indicating that small-diameter neurons associated with processing of noxious thermal stimuli (Caterina et al., 1997) are linked to the presence of zinc in these larger neurons. This intriguing possibility may be important in the modulation of pain transmission along large A-fibers by activity in C-fibers (Willer et al., 1983; Willer and Albe-Fessard, 1983; Seltzer et al., 1991).

Zinc selenite stain in the DRG, observed $1 \mathrm{hr}$ after injection of sodium selenite injected intraperitoneally, does not originate from fast axonal transport from the spinal cord. In support of this is the failure of intrathecal-injected selenite to stain DRG tissue at $1 \mathrm{hr}$. In addition, we found no difference between tissues from control and rhizotomized rats $1 \mathrm{hr}$ after injection of selenite intraperitoneally. Thus, it is unlikely that transport of precipitate from the spinal cord accounts for this stain, consistent with the results obtained using TSQ. Thus, zinc may subserve a special function in the DRG, perhaps involving cell-to-cell communication.

The presence of zinc-positive neurons in the DRG, an area known to be involved in sensation, indicates that zinc plays a role in sensory perception. Zinc has been previously found to interact with NMDA and non-NMDA receptors, which are proposed to play an important role in nociceptive transmission (Peters et al., 1987; Koh and Choi, 1988; Christine and Choi, 1990). [ $\left.{ }^{3} \mathrm{H}\right] \mathrm{MK}-$ 801 (dizocilpine)-binding, which labels NMDA channels, has been found to be especially sensitive to the inhibitory effect of zinc in the spinal cord when compared with binding in the brain (Kovács and Larson, 1997). These data are consistent with our demonstration that changes in zinc availability modulate responses in several nociceptive assays (Larson and Kitto, 1997). Alternatively, the activity of dozens of methalloenzymes in neuronal tissue may be influenced by zinc availability.

In summary, our previously reported behavioral data, demonstrating an influence of zinc on nociceptive responses, together with the present histochemical, fluorescence, and molecular biological data, support a possible role of zinc ions in sensory processing. MT-III mRNA, immunoreactivity, and releasable zinc all appear to be present in capsaicin-insensitive small, primary afferent neurons. In addition, a unique capsaicin-sensitive pool of zinc is paradoxically associated with large DRG neurons. Together, these data suggest a role for this cation in the modulation of sensory transmission.

\section{REFERENCES}

Amoureux M-C, Wurch T, Pauwels PJ (1995) Modulation of metallothionein-III mRNA content and growth rate of rat c6-cells by transfection with human 5HT 1D receptor genes. Biochem Biophys Res Commun 214:639-645.

Andersen RD, Birren BW, Taplitz SJ, Herschman HR (1986) Rat metallothionein-1 structural gene and three pseudogenes, one of which contains 5'-regulatory sequences. Mol Cell Biol 6:302-314.

Aniksztejn L, Charton G, Ben-Ari Y (1987) Selective release of endogenous zinc from the hippocampal mossy fibers in situ. Brain Res 404:58-64.

Arvidson D, Tjälve H (1986) Distribution of ${ }^{109} \mathrm{Cd}$ in the nervous system of rat after intravenous injection. Acta Neuropathol (Berl) 69:111-116.

Assaf SY, Chung S-H (1984) Release of endogenous $\mathrm{Zn}^{2+}$ from brain tissue during activity. Nature 308:735-736.

Caterina MJ, Schumacher MA, Tominaga M, Rosen TA, Levine JD, Julius D (1997) The capsaicin receptor: a heat-activated ion channel in the pain pathway. Nature 389:816-824.

Celestiano JJ, Gyenes M, Gibbs TT, Farb DH (1991) Negative modulation of the $\gamma$-aminobutyric acid response by extracellular zinc. Mol Pharmacol 40:766-773.

Choi DW, Yokoyama M, Koh J (1988) Zinc neurotoxicity in cortical cell culture. Neuroscience 24:67-79.

Christensen M-K, Frederickson CJ, Danscher G (1992) Retrograde tracing of zinc-containing neurons by selenide ions: a survey of seven selenium compounds. J Histochem Cytochem 40:575-579.

Christine CW, Choi DW (1990) Effect of zinc on NMDA receptormediated channel currents in cortical neurons. J Neurosci 10:108-116.

Danscher G (1982) Exogenous selenium in the brain. Histochem 76:281-293.

Danscher G (1984) Do the Timm sulphide silver method and the selenium method demonstrate zinc in the brain? In: Neurobiology of zinc, Vol A (Frederickson CJ, Howell GA, Kasarskis EJ, eds), pp 273-288. New York: Liss.

Dveksler GS, Basile AA, Dieffenbach CW (1992) Analysis of gene expression: use of oligonucleotide primers for glyceraldehyde-3phosphate dehydrogenase. PCR Methods Appl 1:283-285.

Donaldson J, St. Pierre T, Minnich JL, Barbeau A (1973) Determination of $\mathrm{Na}^{+}, \mathrm{K}^{+}, \mathrm{Mg}^{2+}, \mathrm{Cu}^{2+}, \mathrm{Zn}^{2+}$, and $\mathrm{Mn}^{2+}$ in rat brain regions. Can J Biochem 51:87-92.

Fort P, Marty L, Piechaczyk M, Sabrouty S, Dani C, Jeanteur P, Blanchard JM (1985) Various rat adult tissues express only one major mRNA species from the glyceraldehyde-3-phosphate-dehydrogenase multigenic family. Nucleic Acids Res 13:1431-1442.

Frederickson CJ (1989) Neurobiology of zinc and zinc-containing neurons. Int Rev Neurobiol 31:145-238.

Frederickson CJ, Kasarkis EJ, Ringo D, Frederickson RE (1987) A quinoline fluorescence method for visualizing and assaying the histochemically reactive zinc (bouton zinc) in the brain. J Neurosci Methods 20:91-103.

Frederickson CJ, Hernandez MD, Goik SA, Morton JD, McGinty JF (1988) Loss of zinc staining from hippocampal mossy fibers during kainic acid induced seizures: a histofluorescence study. Brain Res 446:383-386.

Gregg RW, Molepo JM, Monpetit VJA, Mikael NZ, Redmond D, Gadia M, Steward DJ (1992) Cisplatin neurotoxicity: the relationship between dosage, time and platinum concentration in neurologic tissues, and morphologic evidence of toxicity. J Clin Oncol 10:795-03.

Howell GA, Perez-Clausell J, Frederickson CJ (1991) Zinc containing projections to the bed nucleus of the stria terminalis. Brain Res 562:181-189.

Howell GA, Welch MG, Frederickson CJ (1984) Stimulation-induced uptake and release of zinc in hippocampal slices. Nature 308:736-738.

Huang Z, Fasco MJ, Kaminsky LS (1996) Optimization of DNase I removal of contaminating DNA from RNA for use in quantitative RNA-PCR. BioTechniques 20:1012-1020.

Knyihár-Csillik E, Bezzegh A, Böti S, Csillik B (1986) Thiamine monophosphatase: a genuine marker for transganglionic regulation of primary sensory neurons. J Histochem Cytochem 34:363-371. 
Kobayashi H, Uchida Y, Ihara Y, Nakajima K, Kohsaka S, Miyatake T, Tsuji S (1993) Molecular cloning of rat growth inhibitory factor cDNA and the expression in the central nervous system. Mol Brain Res 19:188-194.

Koh J, Choi DW (1988) Zinc alters excitatory amino acid neurotoxicity on cortical neurons. J Neurosci 8:2164-2171.

Kovács KJ, Larson AA (1997) Zn2 + inhibition of [3H]MK-801 binding is different in mouse brain and spinal cord: effect of glycine and glutamate. Eur J Pharmacol 324:117-123.

Larson AA, Kitto KF (1997) Manipulations of zinc in the spinal cord, by intrathecal injection of zinc chloride, disodium-calcium-EDTA, or dipicolinic acid, alter nociceptive activity in mice. J Pharmacol Exp Ther 282:1319-1325.

Lees GJ, Lehmann A, Sandberg M, Hamberger A (1990) The neurotoxicity of zinc in the rat hippocampus. Neurosci Lett 120:155-158.

Mandava P, Howell GA, Frederickson CJ (1993) Zinc-containing neuronal innervation of the septal nuclei. Brain Res 608:115-122.

Mannion RJ, Doubell TP, Coggeshall RE, Woolf CJ (1996) Collateral sprouting of uninjured primary afferent A-fibers into the superficial dorsal horn of the adult rat spinal cord after topical capsaicin treatment to the sciatic nerve. J Neurosci 16:5189-5195.

Masters BA, Quaife CJ, Erickson JC, Kelly EJ, Froelick GJ, Zambrowicz BP, Brinster RL, Palmiter RD (1994) Metallothionein III is expressed in neurons that sequester zinc in synaptic vesicles. J Neurosci 14:5844-5857.

Palmiter RD (1987) Molecular biology of metallothionein gene expression. Experientia [Suppl] 52:63-80.

Palmiter RD, Fidley SD, Whitemore TE, Durnam DM (1992) MT-III, a brain-specific member of the metallothionein gene family. Proc Natl Acad Sci USA 89:6333-6337.

Perez-Clausell J, Danscher G (1985) Intravesicular localization of zinc in rat telencephalic boutons. A histochemical study. Brain Res 337:91-98.

Peters S, Koh J, Choi DW (1987) Zinc selectively blocks the action of $N$-methyl-D-aspartate on cortical neurons. Science 236:589-592.

Seltzer Z, Paran Y, Eisen A, Ginzburg R (1991) Neuropathic pain behavior in rats depends in the afferent input from nerve-end neuroma including histamine-sensitive C-fibers. Neurosci Lett 115:203-206.

Shiraishi K, Nakazawa S, Ito H (1993) Zinc enhances kainate neurotoxicity in the rat brain. Neurol Res 15:113-116.

Slomianka L, Danscher G, Frederickson CJ (1990) Labeling of the neurons of origin of zinc-containing pathways by intraperitoneal injections of sodium selenite. Neuroscience 38:843-854.

Uchida Y, Takio K, Titani K, Ihara Y, Tomonaga M (1991) The growth inhibitory factor that is deficient in the Alzheimer's disease brain is a 68 amino acid metallothionein-like protein. Neuron 7:337-347.

Weiss JH, Hartley DM, Koh J, Choi DW (1993) AMPA receptor activation potentiates zinc neurotoxicity. Neuron 10:43-49.

Westbrook GL, Mayer ML (1987) Micromolar concentrations of $\mathrm{Zn}^{2+}$ antagonize NMDA and GABA responses of hippocampal neurons. Nature 328:640-643.

Willer J-C, Albe-Fessard D (1983) Further studies on the role of afferent input from relatively large diameter fibers in transmission of nociceptive messages in humans. Brain Res 208:318-321.

Willer J-C, Boureau F, Albe-Fessard D (1983) Human nociceptive reactions: effect of spatial summation of afferent input from relatively large diameter fibers. Brain Res 201:465-470.

Xie X, Smart TG (1994) Modulation of long-term potentiation in rat hippocampal pyramidal neurons by zinc. Pflügers Arch 427:481-486.

Yagle MK, Palmiter RD (1985) Coordinate regulation of mouse metallothionein I and II genes by heavy metals and glucocorticoids. Mol Cell Biol 5:291-294. 